\title{
Asymmetry of Interest Rate Pass-Through in Albania
}

\author{
Ilda Malile ${ }^{1}$
}

\author{
European University of Tirana
}

\section{Doi:10.5901/ajis.2013.v2n9p539}

\begin{abstract}
This study tries to investigate the asymmetry of interest rate pass-through in Albania over the period 2002m01: 2013m03. An OLS (Ordinary Least Square) approach is employed to take into account solely the long-run dynamics of such asymmetry. More specifically, the study attempts to investigate whether responses of wholesale (represented by the interbank and T-bills' yields) and retail interest rates (deposit and credit) to downward and upward changes in the policy rate are symmetric or not. To the best of our knowledge, this is the first attempt focusing on the asymmetry of the interest rate pass-through, extending the author's previous study (unpublished, to be presented at EBEEC Conference in Istanbul, 9-12 May), which focused mainly on the speed and magnitude of the interest rate pass-through, over a shorter time period. Main findings of this study show that the pass-through of key policy rate to wholesale and retail interest rates is asymmetric. More specifically, the 7-day interbank rate, the 6- and 12-month T-bills' yields and the deposit rate react more strongly to a negative change rather than to a positive change in policy rate. We believe that the empirical results of this study might be useful for the increase in the efficiency of monetary policy implementation, providing useful information of the Albanian monetary policy transmission mechanism.
\end{abstract}

Keywords: asymmetry of interest rate pass through, OLS, monetary policy transmission mechanism

\section{Introduction}

It is widely proven, theoretically and empirically, that monetary policy affects real economy through various channels, among which the most common are: interest rate channel, exchange rate channel and credit channel. In case of Albania, there have been many studies attempting to investigate the monetary policy transmission mechanism, such as: Kolasi et al.(2010) , Vika(2007), Istrefi and Semi (2007), Tanku(2007), Tanku(2008), Shijaku (2010), Kodra (2010), Mançellari (2009), etc. These studies try to estimate the impact of a change in monetary policy on M3, inflation, gross domestic product, exchange rate, credit to private sector, optimal level of reserve holdings, fiscal indicators, monetary and financial conditions, etc. However, it is argued that response of market and retail interest rates to monetary policy rate plays an important role in most of monetary policy transmission channels (especially in the credit and interest rate channel). The speed and magnitude that monetary policy will convey through transmission channels depend on the characteristics of the monetary policy rate pass-through to other interest rates of interbank, primary and retail market. Such pass-through has been the focus of a preceding study², which has estimated the transmission of monetary policy rate to wholesale interest rates (interbank and T-bills' yields) and to retail interest rates (deposit and lending interest rates), by using a VECM methodology, over the period 2006m01:2013m03. However, this paper adds to the previous study by focusing on the asymmetry of policy rate pass-through over a longer period, from the first month of 2002 to the third month of 2013 (135 observations). Asymmetry of interest rate pass-through helps in better understating the transmission process and also in better forecasting the response of wholesale and retail interest rates. Also, asymmetry of overarching passthrough (from monetary policy rate to lending and deposit rates) might give some explanations into the pricing behavior of banks.

Literature on asymmetry of interest rate pass-through points out several indicators which might contribute to such asymmetry (Roelands, 2012; and Jamilov and Égert, 2013), such as: bank regulation and specifics (capital and liquidity requirements, the assessment of credit risk by banks, the level of liquidity in the banking sector, maturity mismatch of

\footnotetext{
1 Views expressed here are those of the authors, and do not necessarily represent views of the European University of Tirana.

2 The preceding study, titled: "The interest rate pass-through in Albania from monetary policy rate to wholesale interest rates and to retail market rates", was presented in the 5th International Conference, "The Economies of Balkan and Eastern Europe Countries in the Changed World", held in Istanbul, Turkey on 9-12th May, 2013. The study is in the publishing process, and is available by the author upon request.
} 
loan and deposit portfolio, level of competition in the banking sector, type of bank customers, level of economic growth, credibility of monetary policy, etc. ).

Literature on the asymmetry of interest rate pass-through can be divided into two main groups: the one focusing on advanced economies, and the rest on developing economies. The former group finds that interest rate-pass through is sluggish and asymmetric. So, Roelands (2012) using interest rates data for United States bank holding companies, over 2001Q1-2012Q1, finds evidence in favor of asymmetry in interest rate pass-through, which is attributed to bank regulations in terms of capital and liquidity requirements. More specifically, Roelands (2012) finds that banks with capital constraints charge higher loan rates than unconstrained ones. Also, the pass-through of federal funds rate to these banks' loan rates is lower, in both cases, accommodative and tightening monetary policy.

On the other hand, literature on developing economies finds that interest rate-pass through is incomplete, but does not find conclusive evidence on the asymmetric elements. Jamilov and Égert (2013) investigates the nature of interest rate pass through in five Caucasian economies (Armenia, Azerbaijan, Georgia, Kazakhastan, and Russia) by using an ARDL methodology on monthly interest rates time series. Jamilov and Égert (2013) attempts to provide answer to a question quite relevant to the topic of this paper: Is there any asymmetric adjustment for the pass-through of policy rate to short- and long-term market rates, and for the overarching pass-through of policy rate to bank deposit and lending rates, in any of the countries under study? It is also important to note that the ARDL methodology in Jamilov and Égert (2013) allows studying for several types of asymmetries: speed of adjustment; long-term relationship, and short-run dynamics. A main finding of Jamilov and Égert (2013) is there is no difference in market rates response regardless the stance of monetary policy (contractionary or expansionary) for the case of Armenia, Azerbaijan, and Russia. In the other two countries, Georgia and Kazakhastan, there are some asymmetric effects, though not statistically significant. Finally, the study finds that asymmetry is stronger at long-term maturities.

Another study investigating the potential asymmetries in the interest rate pass-through is that of Sznajderska (2012). Using threshold autoregressive and momentum-threshold autoregressive model, Sznajderska (2012) examines the asymmetries in the pass-through from money market rates to retail interest rates during the period 2004-2011. Also, using threshold autoregressive models and momentum-threshold autoregressive models, Sznajderska (2012) examines whether deposits and lending rates in Polish commercial banks are asymmetrically adjusted to changes in interbank rates, by checking both, in long- and short-term. One of the findings of the study is that Polish banks adjust the interest rates for credits given to firms and house purchases quicker when error correction term is above the threshold value, due to strong competition for these types of credits and due to adverse selection problem. Another finding is that banks in Poland are faster in adjusting their rates for credits to sore proprietors and for consumer credits, when the error corrections term is below their threshold values. Sznajderska (2012) finds inconclusive evidence regarding the response of interest rates under study to negative and positive changes in money market interest rates.

Kovanen (2011) analyses the interest rate pass-through in Ghana, with a special focus on asymmetry. The author finds empirical evidence in support of asymmetry in the pass-through from policy rate to wholesale rates, which are argued to be due to not very strong policy credibility and to liquidity management. Kovanen (2011) adopts the VAR methodology and introduces some additional variables (spread between each of the wholesale interest rate with the base rate) and judges about the asymmetric properties of such pass-through based on the sign of these "spreads" indicators.

To the best of our knowledge, there is no study in case of Albania investigating the asymmetry of pass-through from policy rate to primary and interbank rates and of the overarching pass-through from policy rate to retail interest rates (lending and deposit). Compared to the preceding study, this one will focus only on the long-term asymmetry of passthrough, and will leave it to future research the study of asymmetry, regarding the short-term and speed of adjustment. The rest of this study briefly explains the data and the methodology employed by the study, and also offers some results having in mind data and methodology limitations. The final section present concludes and provides some suggestions for further areas of research or improvement.

\section{Data, Methodology and Empirical Results}

As mentioned above, this paper aims to study the asymmetric effects of the interest rate pass through in Albania, over the period 2001m01 - 2013m03. More specifically, it studies whether interest rates of interbank and primary market, and also of retail market react symmetrically to negative or positive changes. Wholesale interest rates are presented by the overnight ( $\left.0 \_n\right)$ and 7-day ( $\left.i_{-} 7 d\right)$ interest rate; while the primary market is presented by its three short-term maturities: 3month $\left(b \_3 m\right), 6$-month $\left(b \_6 m\right)$ and 12-month T-bills' yields $\left(b \_12 m\right)$. We choose not to include yields of obligations in the empirical estimation due to their recent launch in the market, which make their time series short. So, auctions of 2-, 3, and 5-year government bond date back in 2002Q4, 2005Q2, and 2006Q4, respectively. Also, frequency of these 
auctions is not very often (every month for the 2-year government bonds, every three months for the 3-and 5-year ones, and quite rarely for the 7-year government bonds though recently its frequency is increasing). The retail market interest rates are represented by the lending (i_credit) and deposit rates (i_deposit) denominated in ALL and applied to newly extended loans and newly collected loans. We choose not to use the rates applied to the stock of loans or deposits as they tend to react more slowly to any changes in policy rate or other rates.

In this study we focus only on the long-term asymmetry of the interest rate pass-through and for this purpose we employ the OLS (Ordinary Least Square) estimation. According to Engle and Granger (1987), any linear combination of two or more non-stationary variables might result to be a stationary series I(0), and if such linear combination does exist, then we might conclude that such regression (linear combination) represents the cointegrating equation and can be interpreted as the long-term relationship between these variables.

Prior to conducting OLS estimation following Engle and Granger (1987), we perform unit root test on each of the interest rate time series using threes tests for robustness check: Augmented Dickey Fuller (ADF), Phillips Perron (PP), and Kwiatkowski-Phillips-Schmidt-Shin (KPSS). Literature on unit root tests (Pelgrin, 2012) suggests that the first two tests are almost similar to each, but they might have some slight differences in finite samples. They are both sensitive to structural breaks, and therefore we have performed a third unit root test, KPSS, which is mostly used in literature in order to get confirmatory results on the unit root process of the time series of our interest. However, our judgment is mostly based on the first two tests (ADF and PP). It is usually believed that interest rates are nonstationary variables, which seems to be proven in the case of Albania. All time series, but credit interest rate, are stationary at first difference at $1 \%$ level of confidence, according to the ADF and PP unit root tests ${ }^{3}$. Therefore, they all enter the OLS estimation as I(1) variables. Credit interest rate is the only variable, which according to two tests (ADF and PP) is stationary at level. For this reason, the results regarding the response of credit interest rate to positive or negative changes in monetary policy rate should be taken with a grain of salt.

This study follows quite a simple technique (the same approach adopted by Tanku, 2007) in order to account for asymmetric effects in the interest rates pass-through, which consists in introducing dummies. So, we construct a dummy coded 1 if there is a negative change in policy rate and zero otherwise to account for expansionary monetary policy. We construct another dummy coded 1 if there is positive change and zero otherwise, to account for contractionary monetary policy stance. Both these dummies enter OLS estimation of each pair of interest rates and the overall reaction to policy rate is obtained by summing up each slope dummy with the coefficient before the policy rate. So, the response of any interest rate to a contractionary monetary policy will be the coefficient before the base rate summing the coefficient before the dummy taking values of 1 for positive changes in policy rate and zero otherwise. This holds also for response of interest rates to expansionary monetary policy.

The results obtained from the OLS estimation are presented in Table 1. In the last column of the table, the unit root tests of the residuals obtained from each of the equations are shown. Based on the p-values, residuals of almost all equations are stationary at $5 \%$ level of confidence, which means that all pairs of interest rates (policy rate with each of the other interest rates) are cointegrated in the long-term. The only exception is the 3-month T-bills - policy rate relationship, whose residuals result to be nonstationary, indicating that there is no long-term co-movement between them two. Also, it is noteworthy to recall that regression of credit interest rate and policy rate should be taken with some doubt since they are of different order of integration, which might cause a spurious regression.

An obvious finding is that all interest rates (of interbank, primary and retail market) are highly dependent on the policy rate, with the long-term coefficient before policy rate being statistically significant and of high positive magnitude. This confirms also the results of the preceding study on the interest rate pass through.

As results of Table 1 show, the sign of the dummy capturing the effect of a contractionary monetary policy is negative in almost all the equations, while the sign of the dummy capturing the effects of an expansionary monetary policy is positive. This indicates that the 7-day interest rate of interbank market, 6-month and 12-month T-bills' yields, and deposit rate react more strongly to a negative change (expansionary) rather than to a positive change (contractionary) in monetary policy rate. There are only two exceptions. One exception is the overnight interest rate, which reacts more to an increase in monetary policy rate. Another exception is the credit interest rate which results to follow more the path of an expansionary monetary policy, which is quite expected, especially given the recent times when Bank of Albania has consecutively decreased the monetary policy rate at its historical minimum, 3.75\% without being 
followed by decreases in credit interest rates. However, as mentioned above the credit-policy rate relationship should be taken with caution.

Table 1. Results on the asymmetry of long-term interest rate pass-through in Albania

\begin{tabular}{|c|c|c|c|c|}
\hline \multirow{2}{*}{ Dependent Variable } & \multicolumn{3}{|c|}{ Explanatory Variables } & \multirow{2}{*}{$\begin{array}{l}\text { Unit root of OLS } \\
\text { residuals ( } p \text {-value) }\end{array}$} \\
\hline & repo_rate & dummy_increase & dummy_decrease & \\
\hline \multicolumn{5}{|l|}{ interbank market } \\
\hline O_n & $0.535099 * * *$ & -0.03093 & $-0.348552 *$ & 0.0144 \\
\hline i_7d & $0.982546^{* * *}$ & $-0.363999 * * *$ & $0.361093 * * *$ & 0.0000 \\
\hline \multicolumn{5}{|l|}{ primary market } \\
\hline b_3m & $1.161751^{* * *}$ & $-0.4163703^{* *}$ & $0.344660 * *$ & 0.1279 \\
\hline $6 \_6 \mathrm{~m}$ & $1.245513^{* * *}$ & $-0.477859 * *$ & $0.364471^{* *}$ & 0.0337 \\
\hline b_12m & $1.210858^{* * *}$ & $-0.571433^{* *}$ & $0.459639 * *$ & 0.0375 \\
\hline \multicolumn{5}{|l|}{ retail market } \\
\hline i_credit & $0.614492^{* * *}$ & 0.341129 & -0.180368 & 0.0001 \\
\hline i_deposit & $0.870839 * * *$ & $-0.550057^{* * *}$ & $0.400464^{* * *}$ & 0.0088 \\
\hline
\end{tabular}

\section{Conclusions, and Further Areas of Research}

The aim of this study was to investigate the long-term asymmetry of interest rate pass-through in case of Albania, as a follow-up study of the previous material, which focused solely on the pass-through (its speed of adjustment, short- and long-term dynamics). This study, employing an OLS approach found evidence for existence of asymmetry from policy rate to all other interest rate taken into consideration, with few exceptions. So, the study found that 7-day interbank rate, 6- and 12-month T-bills' yields and deposit rate react strongly to negative changes (expansionary) in monetary policy rate rather than to positive changes (contractionary). Though these results are based on empirical analysis, we believe there are some issues which could have been taken into consideration and which could have altered slightly some of the results.

First, the analysis would be more complete if we had studied the asymmetric effects of the short-run and speed of adjustment to the long-term equilibrium, already found in our empirical analysis. For that reason, we would have to use some more sophisticated models, like TAR (Threshhold Autoregressive) or VECM incorporating asymmetric elements. Second, in the future we might choose to incorporate other indicators in the estimation which might better explain the asymmetry of the pass-through, such as: capital and liquidity requirements.

Third, it is also crucial to check for any structural breaks in the interest rate time series, as they might distort the results.

\section{References}

Engle, R. dhe Granger, C. 1987. Co-integration and Error Correction: Representation, Estimation and Testing. Econometrica, 55, 251-76 Istrefi, K., and Semi, V., 2007, Exchange rate pass-through in Albania, Bank of Albania Working Paper

Jamilov, R., and Égert, B., 2013, Interest rate pass-through and monetary policy asymmetry: A journey into the Caucasian black box, Document de Travail, Working Paper

Kodra, O., 2010, Estimation of weights for the monetary conditions index in Albania, Bank of Albania Working Paper

Kolasi, G., Shijaku, H., and Shtylla, D., 2010, Monetary transmission mechanism in Albania, Bank of Albania Working Paper

Kovanen, A., 2011, Monetary Policy Tranmission in Ghana: Does the Interest Rate Channel Work?, IMF Working Paper 11/275

Mançellari, A., Macroeconomic effects of fiscal policy in Albania: A SVAR approach, Bank of Albania Working Paper

Pelgrin, F., Unit root test, University of Lausanne, Ecole des HEC, Sept.2012-Dec.2012, ppt

Roelands, S., 2012, Asymmetric interest rate-pass through from monetary policy: the role of bank regulation, University of Notre Dame Shijaku, G., 2010, Optimal level of reserve holdings, an empirical investigation in the case of Albania, Bank of Albania Working Paper Sznajderska, A., 2012, On the empirical evidence of asymmetry effects in the interest rate pass-through in Poland, National Bank of Poland Working Paper, No. 114

Tanku, A., Gjermeni, I., and Vika, I., 2007, The role of exchange rate in an IT framework, Bank of Albania Working Paper

Tanku, A., The challenges of changing monetary policy setup; what should concern the Bank of Albania, Bank of Albania Working Paper Vika,I.,2007, Role of banks in the monetary policy transmission in Albania, Bank of Albania Working Paper 


\section{Appendix}

Table 1. Unit Root Tests using Augmented Dickey Fuller (ADF), Phillips Perron (PP), and Kwiatkowski-Phillips-SchmidtShin (KPSS)

a) Augmented Dickey Fuller Tests

\begin{tabular}{|l|r|r|r|r|r|r|}
\hline \multirow{2}{*}{ Indicators } & \multicolumn{3}{|c|}{ in levels } & \multicolumn{3}{|c|}{ in first difference } \\
\cline { 2 - 7 } repo_rate & intercept & trend\&intercept & none & intercept & trend\&intercept & none \\
\hline b_3m & 0.9221 & 0.9014 & 0.0937 & 0.0000 & 0.0000 & 0.0000 \\
\hline b_6m & 0.7098 & 0.8496 & 0.1072 & 0.0000 & 0.0001 & 0.0000 \\
\hline b_12m & 0.6659 & 0.8459 & 0.2163 & 0.0000 & 0.0000 & 0.0000 \\
\hline o_n & 0.5132 & 0.6014 & 0.2297 & 0.0000 & 0.0000 & 0.0000 \\
\hline i_7d & 0.5132 & 0.6014 & 0.2297 & 0.0000 & 0.0000 & 0.0000 \\
\hline i_credit & 0.8533 & 0.7322 & 0.1384 & 0.0000 & 0.0000 & 0.0000 \\
\hline i_deposit & 0.0064 & 0.0002 & 0.4585 & 0.0000 & 0.0000 & 0.0000 \\
\hline
\end{tabular}

b) Phillips Perron Tests

\begin{tabular}{|l|r|r|r|r|r|r|}
\hline \multirow{2}{*}{ Indicators } & \multicolumn{3}{|c|}{ in levels } & \multicolumn{3}{c|}{ in first difference } \\
\cline { 2 - 7 } & intercept & trend\&intercept & none & intercept & trend\&intercept & none \\
\hline repo_rate & 0.8393 & 0.7521 & 0.1692 & 0.0000 & 0.0000 & 0.0000 \\
\hline b_3m & 0.5159 & 0.5691 & 0.2856 & 0.0000 & 0.0000 & 0.0000 \\
\hline b_6m & 0.5596 & 0.6833 & 0.2083 & 0.0000 & 0.0000 & 0.0000 \\
\hline b_12m & 0.5998 & 0.6929 & 0.2114 & 0.0000 & 0.0000 & 0.0000 \\
\hline O_n & 0.3115 & 0.5888 & 0.4405 & 0.0000 & 0.0000 & 0.0000 \\
\hline i_7d & 0.8400 & 0.6849 & 0.1449 & 0.0000 & 0.0000 & 0.0000 \\
\hline i_credit & 0.0144 & 0.0001 & 0.4862 & 0.0000 & 0.0000 & 0.0000 \\
\hline i_deposit & 0.4398 & 0.7688 & 0.2161 & 0.0000 & 0.0000 & 0.0000 \\
\hline
\end{tabular}

c) KPSS

\begin{tabular}{|c|c|c|c|c|c|c|}
\hline \multirow[b]{2}{*}{ Indicators } & \multicolumn{3}{|c|}{ in levels } & \multicolumn{3}{|c|}{ in first difference } \\
\hline & intercept & trend\&intercept & none & intercept & trend\&intercept & none \\
\hline repo_rate & 0.8267 & 0.1622 & & 0.1103 & 0.1043 & 80888 \\
\hline b_3m & 0.7551 & 0.2017 & & 0.0622 & 0.0591 & 30000 \\
\hline b_6m & 0.7868 & 0.2133 & & 0.0801 & 0.0682 & 80080 \\
\hline b_12m & 0.6351 & 0.1991 & & 0.0824 & 0.0839 & $\$ 20080$ \\
\hline O_n & 0.1334 & 0.1320 & & 0.0851 & 0.0694 & 80000 \\
\hline$i \_7 d$ & 0.8760 & 0.1141 & " & 0.1085 & 0.0591 & 00000 \\
\hline i_credit & 0.8760 & 0.1141 & & 0.1085 & 0.0591 & 30808 \\
\hline i_deposit & 0.5591 & 0.2235 & 10 & 0.1262 & 0.0845 & 80008 \\
\hline
\end{tabular}

